\title{
Pedotransfer functions to estimate soil water content at field capacity and permanent wilting point in hot Arid Western India
}

\author{
Priyabrata Santra $^{1, *}$, Mahesh Kumar ${ }^{1}$, R N Kumawat ${ }^{1}$, D K Painuli ${ }^{1}$, \\ K M Hati ${ }^{2}$, G B M Heuvelink ${ }^{3}$ and $\mathrm{N} \mathrm{H} \mathrm{Batjes}^{3}$ \\ ${ }^{1}$ ICAR-Central Arid Zone Research Institute (CAZRI), Jodhpur 342 003, India. \\ ${ }^{2}$ ICAR-Indian Institute of Soil Science (ISSS), Bhopal 462 001, India. \\ ${ }^{3}$ ISRIC-World Soil Information, Wageningen, The Netherlands. \\ *Corresponding author. e-mail: Priyabrata.Santra@icar.gov.in
}

MS received 17 August 2016; revised 10 August 2017; accepted 22 August 2017; published online 27 March 2018

Characterization of soil water retention, e.g., water content at field capacity (FC) and permanent wilting point (PWP) over a landscape plays a key role in efficient utilization of available scarce water resources in dry land agriculture; however, direct measurement thereof for multiple locations in the field is not always feasible. Therefore, pedotransfer functions (PTFs) were developed to estimate soil water retention at FC and PWP for dryland soils of India. A soil database available for Arid Western India $(N=370)$ was used to develop PTFs. The developed PTFs were tested in two independent datasets from arid regions of India $(N=36)$ and an arid region of USA $(N=1789)$. While testing these PTFs using independent data from India, root mean square error (RMSE) was found to be 2.65 and 1.08 for FC and PWP, respectively, whereas for most of the tested 'established' PTFs, the RMSE was >3.41 and >1.15, respectively. Performance of the developed PTFs from the independent dataset from USA was comparable with estimates derived from 'established' PTFs. For wide applicability of the developed PTFs, a user-friendly soil moisture calculator was developed. The PTFs developed in this study may be quite useful to farmers for scheduling irrigation water as per soil type.

Keywords. Soil water retention; dry lands; western India; pedotransfer functions; soil moisture calculator.

\section{Introduction}

Fresh water is a precious natural resource that has become scarce over the last few decades (Rijsberman 2006; Schewe et al. 2013). It is projected that rapid population growth, urbanization, and economic prosperity in the next 25 years will make water-related challenges more pressing than the present situation (Vörösmarty et al. 2000). The scarcity of water is more prominent in the dry lands of the world, where the gap between availability and demand of water is large. In spite of acute scarcity of water in dry lands, there is a continuous increase in vegetation coverage and agricultural area in dry lands to support a great share of the global population (Millennium Ecosystem Assessment 2005). Likewise, there is a continuous increase in irrigated area and vegetation coverage in Indian dry lands, which has been exerting a severe pressure on the scarce, available water resources (CAZRI 2008). In the arid region of western India, water for irrigation is mainly available 
from groundwater and through the Indira Gandhi Nahar Project (IGNP). Indiscriminate use of this precious resource has led to multifaceted problems in the region, evidenced by a high rate of groundwater depletion, deterioration of soil quality through accumulation of salt at the surface especially in the canal command areas, and disputes among local communities for the use of scarce water for daily life consumption. In the context of global climate change, water scarcity in the dry lands may exacerbate the desertification process (D'Odorico et al. 2013). Therefore, urgent attention is required for judicious use of available water resources in dry land areas. This may be achieved through proper assessment of the soil water regime in the field.

Characterization of the soil water regime in the field depends mainly on two soil hydraulic properties: water retention $[\theta(h)]$ as a function of soil water potential $(h)$ and hydraulic conductivity $[K(h)]$ as a function of $h$. These two soil hydraulic properties are key inputs for most models dealing with budgeting of water for various purposes (Balland et al. 2008; Wösten et al. 2013).

Soil water content at field capacity occurs in the field after 2-3 days of free drainage from saturation. As the soil continues to dry out and reaches a soil water potential of 15 bar $(1500 \mathrm{kPa})$, most plants will start to wilt; therefore, soil water content at this potential is generally accepted as permanent wilting point (PWP). The potential amount of soil water that can be held between FC and PWP is a widely used measure for the plant available water capacity of a soil.

The difference between moisture content at FC and PWP provides a measure for the maximum amount of water held in soil that may be available for plant growth (depending on actual rainfall amount and distribution, or irrigation). FC and PWP thus are very important parameters for irrigation scheduling. One major problem of these hydraulic properties is that their direct measurement at multiple locations, even within an agricultural field, is time-consuming and expensive (Romano and Palladino 2002). Alternatively, soil hydraulic properties can be estimated using pedotransfer functions (PTFs), which relate hydraulic properties with easily measurable soil properties, such as soil particle size distribution (PSD) and soil organic carbon (OC) content (Rawls et al. 1982; Vereecken et al. 1989; Tomasella and Hodnett 1998; Wösten et al. 1999; Schaap et al. 2001; Minsany et al. 2002; Balland et al. 2008; Botula et al. 2013;
Mohanty et al. 2015; Haghverdi et al. 2015; Khlosi et al. 2016; Zhao et al. 2016).

Concerted efforts in many countries over the last decades have led to the development of several 'established' PTFs for estimating soil water retention (Gupta and Larson 1979; Rawls et al. 1982; Wösten and van Genuchten 1988; Tomasella and Hodnett 1998; Wösten et al. 1999; Schaap et al. 2001; Minasny and McBratney 2002). Typically, PTFs are not portable with acceptable accuracy, not even when they are developed from large soil databases (Tietje and Tapkenhenrichs 1993; Wagner et al. 2001; Nemes et al. 2003; Santra and Das 2008). Cornelis et al. (2001) showed that a PTF yields more accurate estimates when it is applied to the geographical region for which it was developed. Similarly, Hodnett and Tomasella (2002) showed that the PTFs developed for temperate conditions performed poorly when applied to deeply weathered soils from tropical humid Brazil. Therefore, PTFs specifically developed and tested for soils of 'Arid Western India' (AWI), which is the geographical region delineated in figure 1 (hereafter referred to as 'arid soils' of India or abbreviated as SAWI) are required for characterization of the soil water regime and land use planning in these dry lands.

There are several PTFs for estimating soil water content at $1 / 3$ bar (FC) and 15 bar (PWP) for other agro-ecological zones of India as well as for use at national scale (Singh 2000; Santra and Das 2008; Adhikary et al. 2008; Chakraborty et al. 2011; Patil et al. 2012; Shwetha et al. 2013). Therefore, the main objective of this study was to develop PTFs for arid soils of India to estimate soil water content at FC and PWP. These PTFs were evaluated and compared with several 'established' (i.e., widely cited) PTFs, using an independent dataset, to assess their reliability for wider application in arid regions. As use of a case example, the applicability of the developed PTF was demonstrated through development of a user-friendly soil moisture calculator in support of agricultural planning.

\section{Materials and methods}

\subsection{Arid Western India}

Arid Western India (AWI) mainly comprises the western part of Rajasthan and north-western part of Gujarat with some parts of Haryana and Punjab at its northeast and east, respectively 


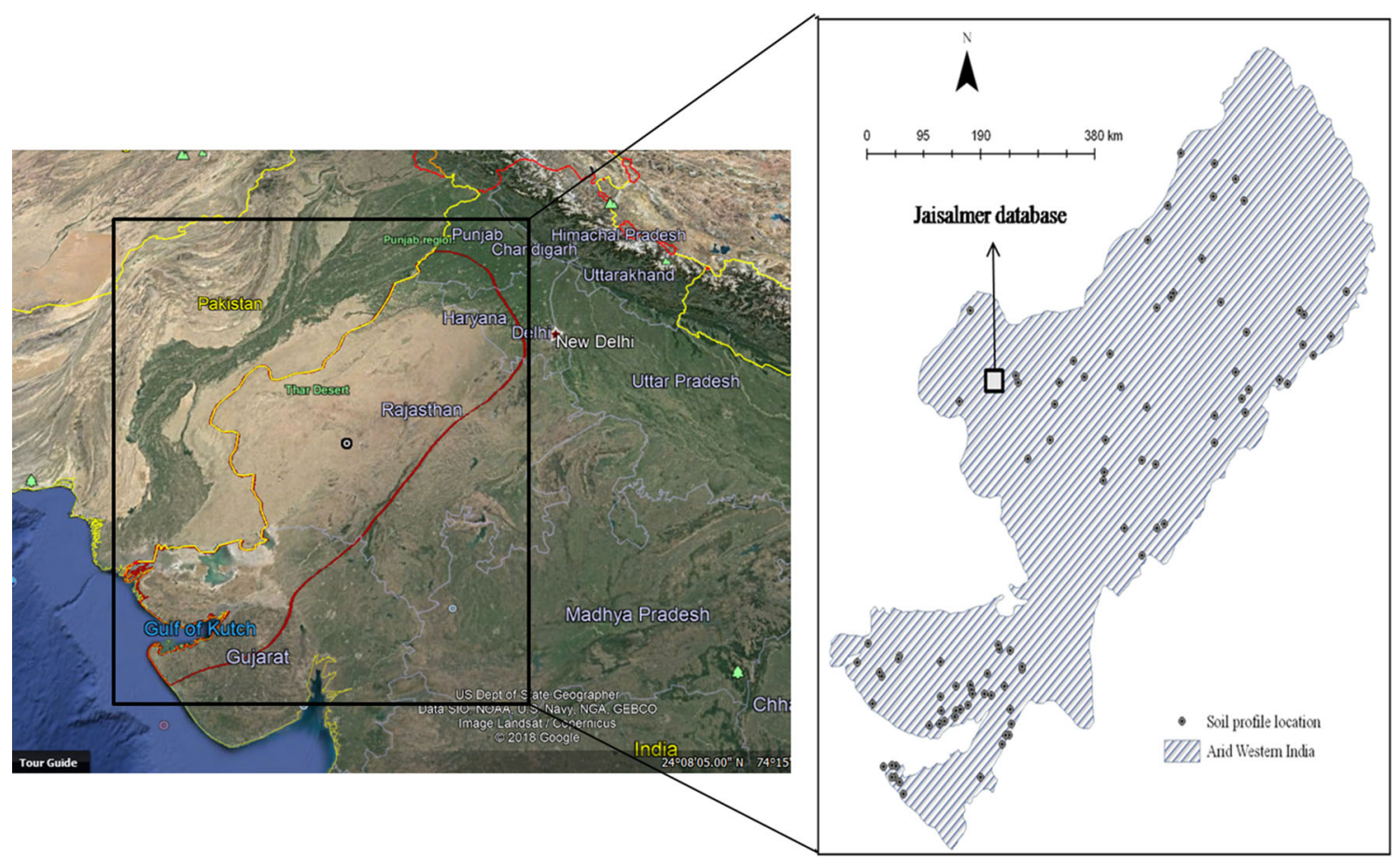

Figure 1. Hot arid ecosystem in India with soil profile locations.

(figure 1). It lies between $21^{\circ} 17^{\prime}-31^{\circ} 12^{\prime} \mathrm{N}$ and $68^{\circ} 8^{\prime}-76^{\circ} 20^{\prime} \mathrm{E}$, covering an area of 32 million ha.

The southern, coastal part of the AWI is locally known as 'Kachch'. The central western and northwestern parts of the region are dominantly covered with high and low dunes with an average height of 10-15 m, which are locally known as 'Marusthali'. The mean annual rainfall in the AWI is $400 \mathrm{~mm}$. The 'Marusthali' region receives less rainfall (200$300 \mathrm{~mm} / \mathrm{yr}$ with $12-15$ rainy days, mostly during July-September) than the 'Kachch' region (350$450 \mathrm{~mm} / \mathrm{yr}$ with 16-18 rainy days during JulySeptember). The mean summer temperature at the 'Marusthali' region is as high as $49^{\circ} \mathrm{C}$ during the day and decreases to less than $20^{\circ} \mathrm{C}$ during the night. The mean day temperature in the coastal part of 'Kachch' is $36-38^{\circ} \mathrm{C}$, which is low compared to the western and northern plains with dune areas.

Main soil types of the SAWI region, defined according to USDA Soil Taxonomy (Soil Survey Staff 2010), include Aridisols (37.8\%), Entisols $(50.1 \%)$, and Inceptisols (13.1\%) (figure 2 and table 1). Aridisols are mainly observed in buried pediments, interdunal plains and old alluvial plains. Average depth of such profiles is $106 \mathrm{~cm}$ with well-demarcated horizons; concretions of calcite below the soil profile are common. Psamments-Orthids are the major sub-order association under Aridisols. Average bulk density of these soils is $1.46 \mathrm{Mg} \mathrm{m}^{-3}$ and average sand, silt and clay content about $61 \%, 16 \%$ and $23 \%$, respectively. Entisols are found in places where aeolian activity is dominant with Orthids-Psamments as major sub-order association. Average depth of Entisols is $105 \mathrm{~cm}$ and the bulk density $1.54 \mathrm{Mg} \mathrm{m}^{-3}$. Surface horizons are richer in sand content than subsurface horizons; the average sand, silt and clay content is $78 \%, 9 \%$ and $13 \%$, respectively. Soils under Inceptisols are mainly observed at western and southern borders of Arid Western India with Ochrepts as the dominating soil sub-order. Average soil depth under Inceptisols is $83 \mathrm{~cm}$, average sand, silt and clay content is $51 \%, 15 \%$ and $34 \%$, respectively whereas average bulk density is $1.51 \mathrm{Mg} \mathrm{m}^{-3}$.

\subsection{Soil database from arid western India}

The National Bureau of Soil Survey and Land Use Planning (NBSS\&LUP), India, carried out comprehensive soil surveys for different states, including Rajasthan (Shyampura et al. 2002) and Gujarat (Sharma et al. 2006), which lie in Arid Western India. The corresponding survey reports contain measured data on particle size distribution, organic carbon (OC) content $\left(\mathrm{g} \mathrm{kg}^{-1}\right), \mathrm{pH}$, electrical conductivity $\left(\mathrm{dS} \mathrm{m}^{-1}\right)$, free $\mathrm{CaCO}_{3}$ content $(\%, \mathrm{~g} / \mathrm{g})$, FC and PWP $(\%, \mathrm{~g} / \mathrm{g})$ as well as data on exchangeable bases and major nutrient contents, and these 


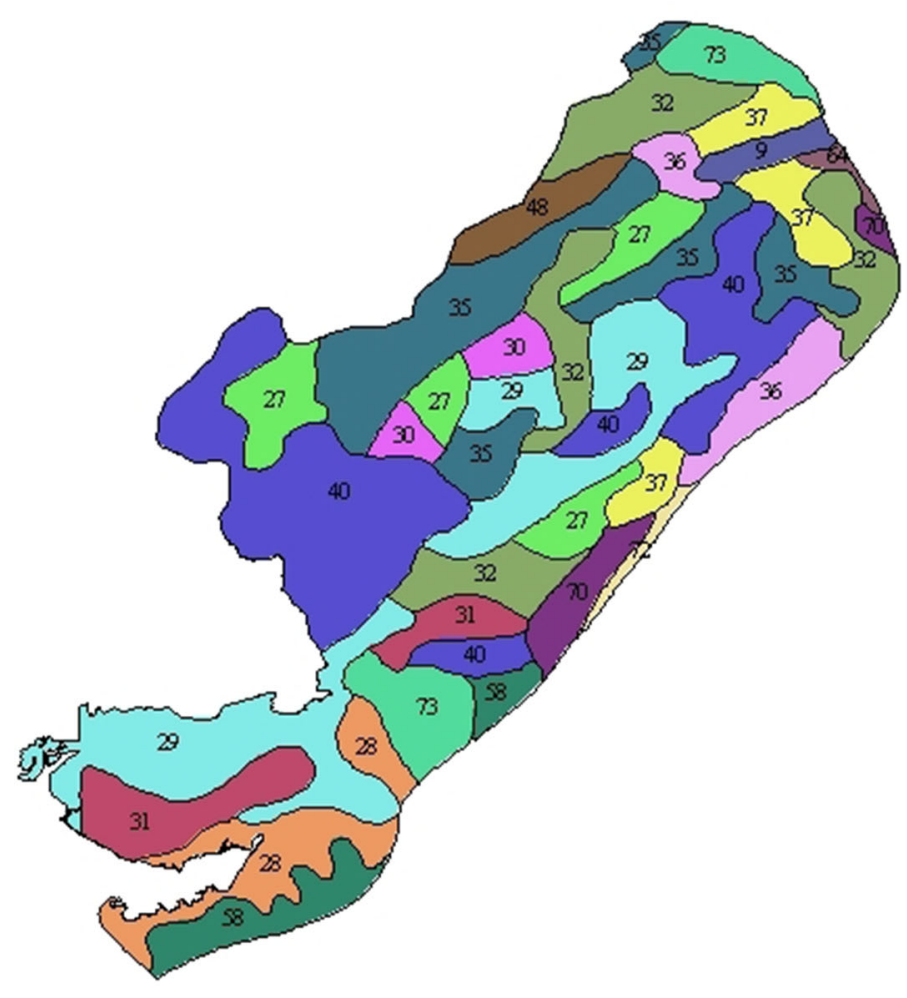

\section{Soil Mapping Unit and Sub ord er associations}

\begin{tabular}{l}
\hline Ustalf Ochrepts \\
27 Orthids \\
28 Orthids Aquepts \\
29 Orthids Psamments \\
30 Orthids Orthents \\
31 Orthids Argids \\
32 Orthids Fluvents \\
35 Orthids Argids \\
36 Orthids Psamments \\
37 Psamments Fluvents Orthids \\
40 Psamments Orthids \\
48 Fluvents Orthids \\
58 Orthents Orchepts \\
64 Aquepts Ochrepts \\
70 Ochrepts \\
\hline$\square 2$ Ochrepts Orthents \\
73 Ochrepts Psamments \\
\hline$\square$ \\
\hline$\square$ \\
\hline$\square$
\end{tabular}

Figure 2. Soil suborder association map of hot Arid Western India. Numbers refer to mapping units as described in table 1.

were digitalized. The soil database for Arid Western India (SAWI) was collated from the state level databases for Rajasthan and Gujarat (Shyampura et al. 2002; Sharma et al. 2006) by extracting those soil profiles lying within the AWI region and having data on particle size distribution, OC content, FC and PWP. This yielded a total of 93 soil profiles, of which 50 were from western Rajasthan and 43 from northwestern Gujarat.

\subsection{Development datasets}

The data on soil particle size distribution in the SAWI database were available for five size fractions: very coarse sand $(1-2 \mathrm{~mm})$, coarse sand $(0.5-1 \mathrm{~mm})$, fine sand $(0.05-0.5 \mathrm{~mm})$, silt $(0.002-$ $0.05 \mathrm{~mm})$ and clay $(<0.002 \mathrm{~mm})$. However, other soil survey reports from India mostly contain data on only three fractions: sand $(0.05-2 \mathrm{~mm})$, silt $(0.002-0.05 \mathrm{~mm})$ and clay $(<0.002 \mathrm{~mm})$. Keeping in mind the future applications of the developed PTFs in India, the most commonly available particle size fractions (sand, silt and clay) and $\mathrm{OC}$ content were selected as predictor variables in the
PTFs. In total, the SAWI database contained data for 380 soil horizons having data for sand, silt and clay content as well as OC content, FC and PWP. Further, to develop robust PTFs for dryland soils in the world, the SAWI database was merged with a database representing major soils types from arid USA (see below).

\subsection{Testing datasets}

To test the developed PTFs, two independent datasets were prepared, which are also different from the development dataset. The first was generated for the Jaisalmer district within AWI (see figure 1). Seventeen profiles were excavated representing different land-use situations in the Thar desert to collect 78 soil samples. All collected soil samples were analyzed in the laboratory to determine bulk density by core method, particle size distribution by pipette method, OC content by Walkley and Black method (Walkley and Black 1934), and water retention at $1 / 3$ bar and 15 bar by pressure plate apparatus method (Klute 1986). The 


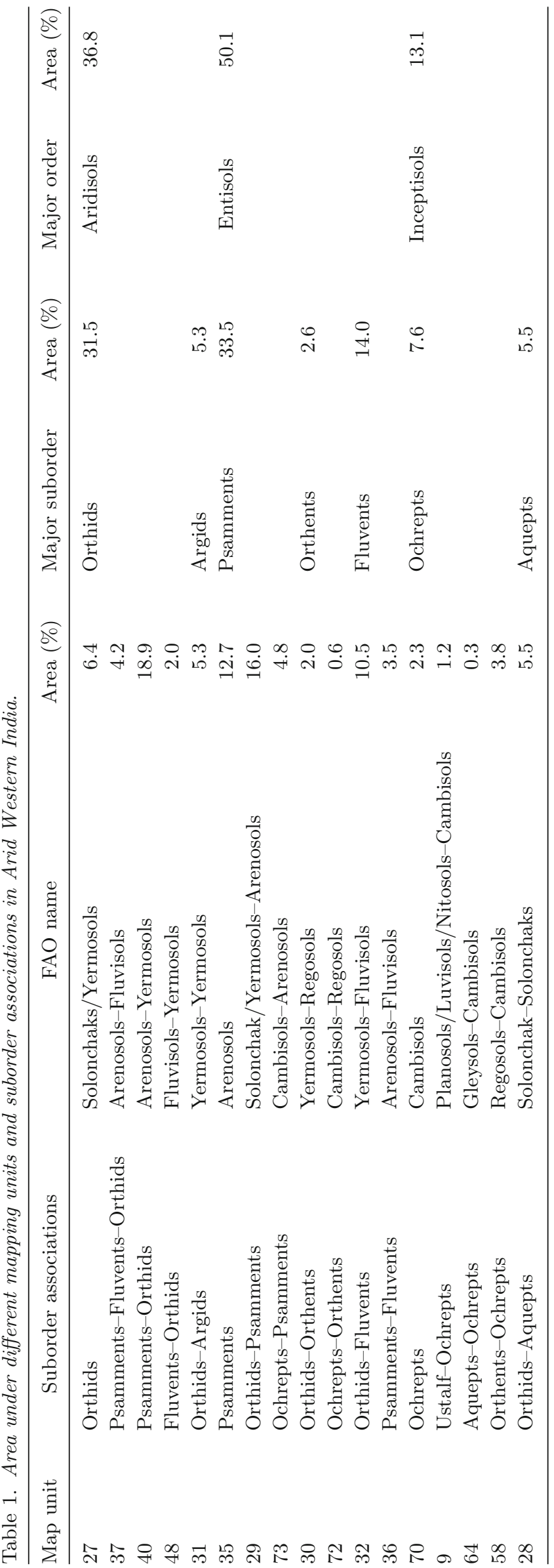

Table 2. Detail composition of soil database from arid region of USA used in this study.

\begin{tabular}{|c|c|}
\hline County & No. of samples \\
\hline \multicolumn{2}{|c|}{ Arizona state $(N=93)$} \\
\hline Cochise & 93 \\
\hline \multicolumn{2}{|c|}{ California state $(N=521)$} \\
\hline Inyo & 80 \\
\hline Kern & 235 \\
\hline Los Angeles & 9 \\
\hline Orange & 38 \\
\hline Riverside & 15 \\
\hline San Bernardino & 113 \\
\hline San Diego & 10 \\
\hline Santa Barbara & 21 \\
\hline \multicolumn{2}{|c|}{ Nevada state $(N=1175)$} \\
\hline Churchill & 75 \\
\hline Clark & 81 \\
\hline Douglas & 10 \\
\hline Elko & 201 \\
\hline Esmeralda & 50 \\
\hline Eureka & 22 \\
\hline Humboldt & 68 \\
\hline Lander & 115 \\
\hline Lincoln & 51 \\
\hline Lyon & 27 \\
\hline Mineral & 26 \\
\hline Nye & 134 \\
\hline Pershing & 106 \\
\hline Washoe & 127 \\
\hline White Pine & 82 \\
\hline
\end{tabular}

Source: NCCS Soil Characterization Database (http://ncsslabdatamart.sc. egov.usda.gov/).

resulting dataset is hereafter referred to as 'Jsm' database.

The second test dataset, with soil profiles from the arid parts of Arizona, California and Nevada states of USA $(N=1789$, table 2$)$, was prepared by downloading the relevant predictor data from the NCCS Soil Characterization Database (http:// ncsslabdatamart.sc.egov.usda.gov/).

\subsection{Methods for measuring soil water retention}

The soil databases from Arid Western India (SAWI) and the arid region of USA (arid-USA) contain data on water retention measured using pressure plate extraction methods (Sarma et al. 1987; Sehgal et al. 1987; Soil Survey Staff 1996; Bhattacharya et al. 2009). In case of water retention data extracted from the NCSS Soil Characterization Database, only samples analyzed according to 
laboratory methods 4B1c and 4B2a were considered. Procedure 4B1c measures water retention, expressed on a $<2 \mathrm{~mm}$ base, using clods at 0.33 bar and pressure-plate extraction, whereas procedure 4B2a measures water retention at 15 bar using $<2 \mathrm{~mm}$ air dry soil samples and pressuremembrane extraction (Soil Survey Staff 1996). Alternatively, as commonly done in many, especially developing countries (Bell and Van Keulen 1996; Klute 1986), the FC data for SAWI were determined on disturbed samples although it is known that structure and macro-porosity of the sample affect water retention (Unger 1975; Young and Dixon 1966; van Reeuwijk 2002) and this especially in the lower suction range except for the coarser textured soils (Bell and Van Keulen 1996); the latter soils predominate in the study region (table 4 and section 3.1). In this study, we used $1 / 3$ bar or $33 \mathrm{kPa}$ as the soil water potential that best corresponds with FC.

\subsection{Data analysis}

\subsubsection{Descriptive statistics}

Mean, standard deviation and range of soil properties in the development database (SAWI) as well as in the testing databases ('jsm' and 'USA-arid') were calculated using $\mathrm{R}$ software ( $\mathrm{R}$ Core Team 2013). The Spearman rank correlation coefficient between soil water retention and basic soil properties was calculated and the correlation matrix prepared. Significance of the correlation coefficient was tested using the $t$-statistic (Gupta and Kapoor 2000).

\subsubsection{PTF development}

Point PTFs for soil water content at FC and PWP were developed using a multiple linear regression (MLR) equation of the form

$$
Y=a_{0}+\sum_{k=1}^{K} a_{k} X_{k}
$$

where $Y$ is the dependent variable, $X_{k}$ is the $k$ th independent variable (input), $a_{0}, \ldots, a_{k}$ are regression coefficients and $k$ is the number of independent variables in the regression equation.

The MLR equations were developed using the linear model $(\mathrm{lm})$ function of $\mathrm{R}$ software. Three major soil properties, namely sand content (\%), clay content (\%) and organic carbon content $(\mathrm{g} / \mathrm{kg})$, and their two-way interactions were used as an initial set of explanatory variables followed by a stepwise approach to remove statistically insignificant terms. Stepwise regression analysis was carried out for two major categories of input data: (i) PSD category containing information on sand and clay content along with their two-way interactions (e.g., sand $\times$ clay) and (ii) PSD+OC category data containing sand, clay and OC content along with their two-way interactions (i.e., sand $\times$ clay, sand $\times$ OC and clay $\times$ OC). Selected sets of inputs in the stepwise approach were further reduced to common sets separately for soil water content at FC and PWP under the two main categories of inputs. These common sets were further used to develop PTFs from the SAWI database and the merged SAWI and USA-arid database.

\subsubsection{Validation of PTFs}

Developed PTFs were first validated using 10-fold cross-validation using the cross-validation function in R. In this approach, the total dataset is randomly divided into 10 subsets. Next the model is developed 10 times, each time calibrating the model on data of nine subsets and testing it on the remaining subset. Bias and root mean square error (RMSE) of estimation were calculated from the predictions of the target variable using:

$$
\operatorname{Bias}=\frac{1}{N} \sum_{i=1}^{N}\left(Y_{i}-\hat{Y}_{i}\right)
$$

$$
\operatorname{RMSE}=\sqrt{\frac{1}{N} \sum_{i=1}^{N}\left(Y_{i}-\hat{Y}_{i}\right)^{2}}
$$

where $Y_{i}$ is an observed value of the target variable, which is either $\theta_{1 / 3 \mathrm{bar}}$ or $\theta_{15 \mathrm{bar}}, \hat{Y}_{i}$ is an estimated value of the same variable and $N$ is the number of observations in the dataset. Lower values of both bias and RMSE indicate better performance of the model. While calculating these two indices, bias gives equal weight to all errors, whereas RMSE assigns more weight to larger errors than smaller errors. Therefore, RMSE can never be smaller than bias. More is the difference between bias and RMSE indicates presence of a few large errors. 
Table 3. List of published pedotransfer functions (PTFs) for estimating soil water content at FC and PWP considered in the comparative study.

\begin{tabular}{|c|c|c|}
\hline Authors & Region & Pedotransfer function ${ }^{\#}$ \\
\hline Schaap et al. (2001) & USA & Artificial neural network based PTFs (Rosetta) \\
\hline Tomasella and Hodnett (1998) & Brazil & $\begin{array}{l}{ }^{*} \mathrm{FC}=4.046+0.426 \times \text { silt }+0.404 \times \text { clay } \\
{ }^{*} \mathrm{PWP}=0.91+0.15 \times \text { silt }+0.396 \times \text { clay }\end{array}$ \\
\hline Adhikary et al. (2008) & India & $\begin{array}{l}{ }^{*} \mathrm{FC}=56.37-0.51 \times \text { sand }-0.27 \times \text { silt } \\
{ }^{*} \mathrm{PWP}=0.71+0.44 \times \text { clay }\end{array}$ \\
\hline Chakraborty et al. (2011) & India & $\begin{array}{l}{ }^{* *} \mathrm{FC}=27.447+0.078 \times \text { clay }+0.248 \times \text { silt }-0.241 \times \text { sand } \\
{ }^{* *} \mathrm{PWP}=20.695+0.021 \times \text { clay }-0.028 \times \text { silt }-0.179 \times \text { sand }\end{array}$ \\
\hline
\end{tabular}

\subsubsection{Testing of PTFs}

The performance of the PTFs developed from the SAWI database was further tested using the 'Jsm' and 'USA-arid' databases. While testing the developed PTFs using independent datasets, their performance was also compared with two national and two international 'established' PTFs; for details see table 3 . It is noted here that the soil database from Arid Western India contains water retention data in gravimetric units $(\%, \mathrm{~g} / \mathrm{g})$. Therefore, throughout this study, gravimetric water content $(\%, \mathrm{~g} / \mathrm{g})$ data were used to develop PTFs for water retention at $1 / 3$ bar and 15 bar. Some of the 'established' PTFs (Schaap et al. 2001; Tomasella and Hodnett 1998; Adhikary et al. 2008) estimate water retention in volumetric units; for comparison purposes, the estimated values were converted to gravimetric units using available data on bulk density.

The PTFs by Schaap et al. (2001), which are commonly known as 'rosetta', were considered here because of their widespread use and the requirement of similar inputs as with the developed PTFs in this study. The PTFs by Tomasella and Hodnett (1998) were selected because these were developed for a tropical/sub-tropical region, although soil conditions are very different. Besides these PTFs, two sets of PTFs developed for India (Adhikary et al. 2008; Chakraborty et al. 2011) were used; these PTFs were developed from a large number of soil samples distributed throughout India and hence may be considered 'national scale' PTFs. The estimation efficiency of the selected PTFs using the test databases was evaluated using RMSE. The PTFs with lower value of RMSE was considered better than the PTFs with higher value of RMSE.

\subsection{Preparation of PTF-based user interface}

For wide applicability of the developed PTFs, a user interface was prepared using Microsoft Visual Studio version 6.0. Drop-down menus were created to include options to choose a particular PTF model. Apart from PTFs developed in this study, the 'established' PTFs were also included in the list; for each of these, only the relevant predictor variables can be entered with simple checks on data entry (e.g., sum of sand, silt and clay should be 100\%). Programming codes were written to estimate soil water content at FC and PWP following the selected PTF model, and to calculate available water capacity per soil layer using

$$
\begin{aligned}
\theta_{\mathrm{AWC}}= & \frac{(\mathrm{FC}-\mathrm{PWP})}{100} \times \text { bulk density }\left(\mathrm{Mg} \mathrm{m}^{-3}\right) \\
& \times \text { depth of soil layer }(\mathrm{mm})
\end{aligned}
$$

where $\theta_{\text {AWC }}$ is the available water capacity of soil in $\mathrm{mm}$, and $\mathrm{FC}$ and PWP are the estimated soil water content at $1 / 3$ bar and 15 bar, respectively, in gravimetric unit $(\%, \mathrm{~g} / \mathrm{g})$.

\section{Results and discussion}

\subsection{Descriptive statistics}

\subsubsection{Development database}

Descriptive statistics of soil properties in the SAWI database are given in table 4 . Soil texture was 


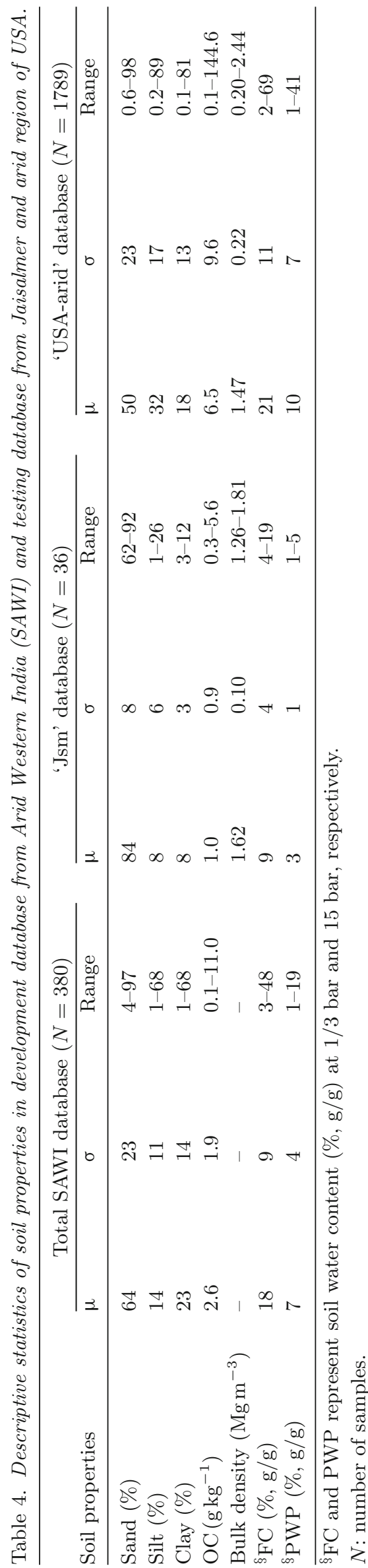

sandy in most cases; however, clay and sandy clay soil texture were also observed for a few soil samples from the southern coastal region of the AWI. Organic carbon content of soils was low with an average content of $2.6 \mathrm{~g} \mathrm{C} \mathrm{kg}^{-1}$. About half of the soil samples have $\mathrm{OC}$ between 0 and $2 \mathrm{~g} \mathrm{C} \mathrm{kg}^{-1}$, while the minimum and maximum are 0.1 and $11 \mathrm{~g} \mathrm{C} \mathrm{kg}^{-1}$, respectively. Average soil water content at $\mathrm{FC}$ was $18 \%(\mathrm{~g} / \mathrm{g})$ and observations varied from $3 \%$ to $48 \%$; average soil water content at PWP was $7 \%(\mathrm{~g} / \mathrm{g})$, with a minimum of $1 \%$ for sandy textured soils and a maximum of $19 \%$ for clay textured soils.

\subsubsection{Testing database}

Descriptive statistics of the 'Jsm' and 'USA-arid' testing databases are given in table 4. Overall, soil properties in the 'Jsm' database are more similar to those of the SAWI database than those of the 'USA-Arid' database. However, overall, soils in 'Jsm' database are more sandy and lower in OC content than soils in the SAWI database, which was also reflected in the water retention at $1 / 3$ bar and 15 bar. In contrast, soils in the 'USAarid' database are quite different from those of the SAWI and 'Jsm' databases, in that there is greater diversity in soil types/series, although all three databases represent soils from arid climate regions. It should be noted that mean OC content in the 'USA-arid' database is higher than in the 'Jsm' and SAWI databases. Sand content of soils was lower, whereas silt and clay content were higher in 'USA-Arid' database than in the 'Jsm' and SAWI databases.

\subsection{Correlation matrix of soil properties from the SAWI database}

The Spearman correlation coefficients $(r)$ among soil properties in the SAWI database are presented in table 5. Sand, silt, clay and OC content were found significantly correlated with soil water content at FC and PWP (figure 3). Soil water content at FC had the highest correlation with sand content $(r=-0.92, p<0.01)$, whereas soil water content at PWP had the highest correlation with clay content $(r=0.95, p<0.01)$. Sand content was observed negatively correlated with water retention at FC and PWP whereas silt, clay and OC content showed positive correlation with water retention at FC and PWP. It indicates that higher is the sand content, lesser will be the soil water retention at 
Table 5. Correlation matrix among soil properties held in the soil database of Arid Western India (SAWI).

\begin{tabular}{lcccccc}
\hline & $\begin{array}{c}\text { Sand } \\
(\%)\end{array}$ & $\begin{array}{c}\text { Silt } \\
(\%)\end{array}$ & $\begin{array}{c}\text { Clay } \\
(\%)\end{array}$ & $\begin{array}{c}\mathrm{OC} \\
\left(\mathrm{g} \mathrm{kg}^{-1}\right)\end{array}$ & $\begin{array}{c}\mathrm{FC} \\
(\%, \mathrm{~g} / \mathrm{g})\end{array}$ & $\begin{array}{c}\text { PWP } \\
(\%, \mathrm{~g} / \mathrm{g})\end{array}$ \\
\hline Sand $(\%)$ & 1 & & & & & \\
Silt $(\%)$ & $-0.85^{* *}$ & 1 & & & & \\
Clay $(\%)$ & $-0.91^{* *}$ & $0.57^{* *}$ & 1 & & & \\
OC $\left(\mathrm{g} \mathrm{kg}^{-1}\right)$ & $-0.51^{* *}$ & $0.35^{* *}$ & $0.53^{* *}$ & 1 & & \\
FC $(\%, \mathrm{~g} / \mathrm{g})$ & $-0.92^{* *}$ & $0.72^{* *}$ & $0.89^{* *}$ & $0.49^{* *}$ & 1 & \\
PWP $(\%, \mathrm{~g} / \mathrm{g})$ & $-0.91^{* *}$ & $0.63^{* *}$ & $0.95^{* *}$ & $0.51^{* *}$ & $0.91^{* *}$ & 1 \\
\hline
\end{tabular}

** Significance level at $1 \%$.

(a)

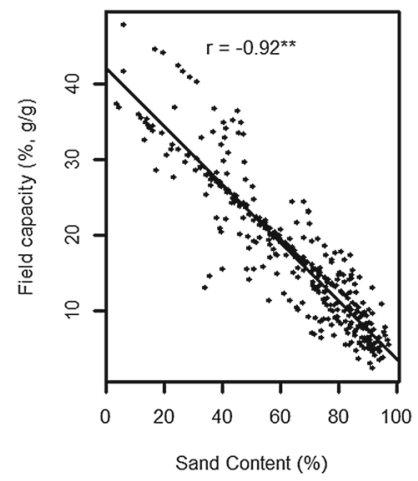

(e)

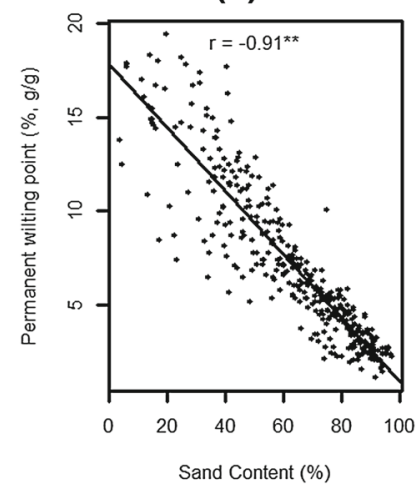

(b)

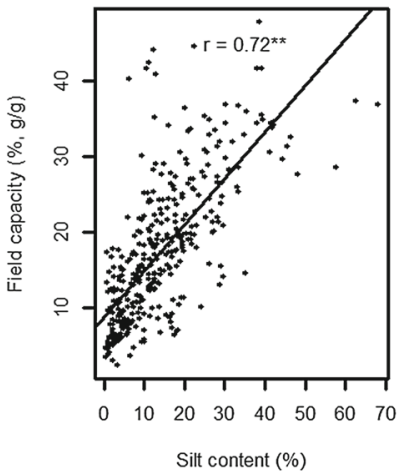

(f)

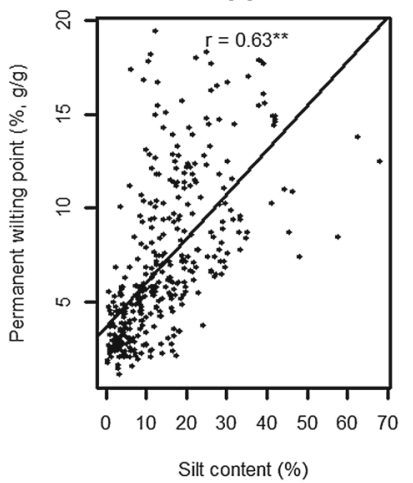

(c)

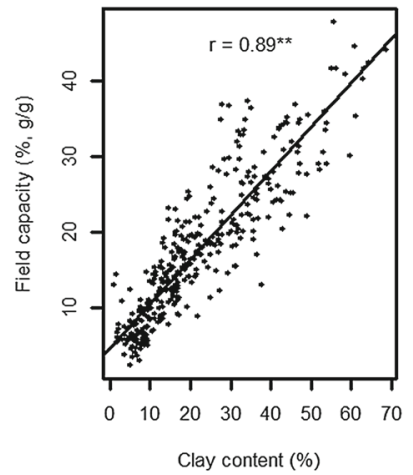

(g)

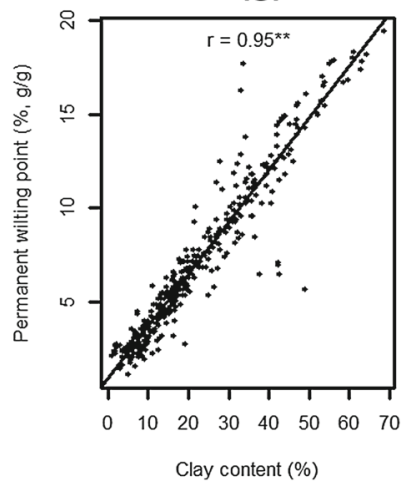

(d)

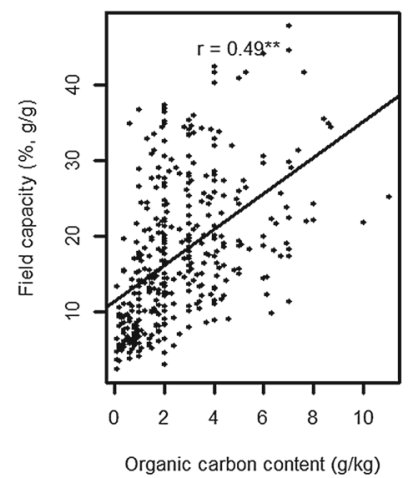

(h)

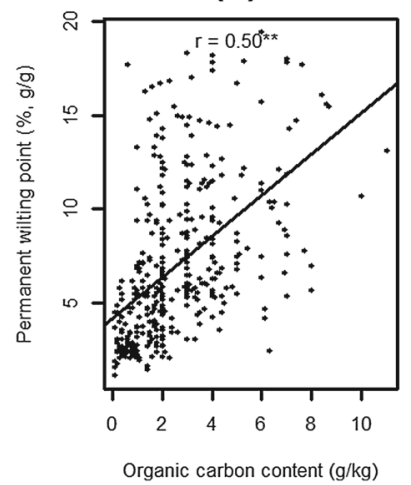

Figure 3. Scatter plots of sand content (\%), silt content (\%), clay content (\%) and organic carbon content (g/kg) with soil water content at field capacity $(\%, \mathrm{~g} / \mathrm{g})$ and permanent wilting point $(\%, \mathrm{~g} / \mathrm{g})$.

FC and PWP whereas higher silt, clay and OC content, leads to higher soil water retention at FC and PWP. Data on particle size distribution showed stronger correlation with soil water retention than OC content. The correlations between OC content and soil water retention were $0.49(p<0.01)$ and $0.51(p<0.01)$, respectively, for FC and PWP.

\subsection{Pedotransfer functions (PTFs)}

Developed PTFs with significant selected inputs using the SAWI database, hereafter referred to as
$\mathrm{PTF}_{\mathrm{SAWI}}$, are presented in table 6 . The $R^{2}$ value of developed regression PTFs for both particle size distribution (PSD) category and PSD+OC category is similar. Including $\mathrm{OC}$ as an independent variable does not improve the regression significantly; this may be due to very low content of OC content in arid soils of India. The predictive performance of PTF models in terms of $R^{2}$ value was higher for $\operatorname{PWP}\left(R^{2}=0.92\right)$ than for $\mathrm{FC}\left(R^{2}=\right.$ $0.87)$. It indicates that predictor variables used in PTF model for PWP explained 92\% variation in PWP data whereas in case of FC, $87 \%$ variation 
Table 6. Local pedotransfer functions $\left(P T F_{S A W I}\right)$ developed with soil data from hot Arid Western India to estimate soil water retention at 1/3 bar and 15 bar.

\begin{tabular}{|c|c|c|c|c|}
\hline \multirow[b]{2}{*}{ Inputs } & \multicolumn{2}{|c|}{ Soil water content at FC $(\%, \mathrm{~g} / \mathrm{g})$} & \multicolumn{2}{|c|}{ Soil water content at PWP $(\%, \mathrm{~g} / \mathrm{g})$} \\
\hline & PSD & $\mathrm{PSD}+\mathrm{OC}$ & PSD & $\mathrm{PSD}+\mathrm{OC}$ \\
\hline Intercept & $29.79^{* * *}$ & $29.77^{* * *}$ & $5.04^{* * *}$ & $1.516^{* * *}$ \\
\hline Sand & $-0.264^{* * *}$ & $-0.263^{* * *}$ & $-0.0385^{* * *}$ & \\
\hline Clay & $0.207^{* * *}$ & $0.206^{* * *}$ & $0.232^{* *}$ & $0.325^{* * *}$ \\
\hline $\mathrm{OC}$ & & 0.0110 & & \\
\hline Sand $\times$ Clay & & & $-0.00057^{* *}$ & $-0.00147^{* * *}$ \\
\hline Sand $\times$ OC & & & & $0.00247^{* *}$ \\
\hline Clay $\times$ OC & & & & $-0.00469^{* *}$ \\
\hline & $R^{2}=0.87$ & $R^{2}=0.87$ & $R^{2}=0.92$ & $R^{2}=0.92$ \\
\hline
\end{tabular}

Values given in the table represents the coefficients of PTF model in the form of multiple linear regression equation as mentioned in equation (1) along with their significant levels.

*** and ${ }^{* *}$ represent significance level at $<0.1 \%$ and $<1 \%$, respectively.

in FC data was explained by predictor variables used in PTF model for FC. Sand content has negative influence on soil water contents at $\mathrm{FC}$ and PWP whereas clay content has positive influence. When OC content was considered as input in addition with PSD, it has been observed that interaction of sand and $\mathrm{OC}$ content has positive influence on water retention whereas interaction of clay and $\mathrm{OC}$ has negative influence on water retention at PWP.

Apart from $\mathrm{PTF}_{\mathrm{SAWI}}$, a set of global PTFs was also developed using the merged database from arid region of India and USA, keeping in mind their potential applicability in drylands anywhere in the world (see table 7 ). The predictive performances of the global PTFs in terms of $R^{2}$ value were lower than for $\mathrm{PTF}_{\mathrm{SAWI}} ; R^{2}$ values were 0.73 and 0.72 for global PTF of FC and PWP, respectively, with $\mathrm{PSD}+\mathrm{OC}$ category. It is noted here that unlike of

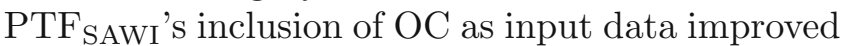
the predictive performance of global PTFs developed from merged database since the OC content of arid soils in USA was comparatively higher than in the SAWI database, specifically for PTF of FC. Regression coefficients of developed global PTFs showed that clay has positive influence on water retention both at FC and PWP. Sand content has been observed to have a negative influence on water retention at FC as depicted by its negative coefficient. Larger influence of clay on soil water content than sand was observed in both SAWI and USAarid database as depicted by their higher value of corresponding regression coefficients. Interaction of sand and clay showed negative influence on soil water content both at FC and PWP. When OC was introduced in PTF model as predictor variable, interaction of sand and clay with $\mathrm{OC}$ was found to positively influence PWP content.

\subsection{Performance of the developed PTFs}

\subsubsection{Cross-validation of PTFs}

Estimated values of soil water content at FC and PWP obtained from 10-fold cross validation of $\mathrm{PTF}_{\mathrm{SAWI}}$ are plotted against observed values in figure 4. Mean absolute and mean squared error of estimated FC were found 2.49 and 11.9, respectively, whereas for PWP it was 0.73 and 1.47, respectively. Therefore, observed and estimated values are observed very close to the 1:1 line for both FC and PWP. The errors of estimations in terms of RMSE were also found very low for both FC and PWP and these were 3.44 and 1.17, respectively.

\subsubsection{Testing of PTFs}

Observed and estimated values of FC and PWP by $\mathrm{PTF}_{\text {SAWI }}$ and those obtained using selected 'established' PTFs were also computed for the independent testing databases, 'Jsm' and 'USA-arid' (figure 5). Scatter plots of observed and estimated values by PTF $_{\text {SAw }}$ and other 'established' PTFs in the 'Jsm' database are presented in figure 5 (a and b). Bias of the estimated values of $\mathrm{FC}$ was found smaller for $\mathrm{PTF}_{\mathrm{SAWI}}-\mathrm{PSD}+\mathrm{OC}\left(-0.17 \mathrm{~g} \mathrm{~g}^{-1}\right)$ than for 'established' PTFs. Similarly, for PWP, bias was smaller for $\mathrm{PTF}_{\mathrm{SAWI}}-\mathrm{PSD}\left(-0.17 \mathrm{~g} \mathrm{~g}^{-1}\right)$ than for other 'established' PTFs except for the PTF of Tomasella and Hodnett (1998) $\left(-0.14 \mathrm{~g} \mathrm{~g}^{-1}\right)$. In general, estimated values of soil water content at FC by the developed PTFs showed negative bias 
Table 7. Global pedotransfer functions (PTFs) developed with soil data from Arid Western Indian and arid regions of USA to estimate soil water retention at 1/3 bar and 15 bar.

\begin{tabular}{|c|c|c|c|c|}
\hline \multirow[b]{2}{*}{ Inputs } & \multicolumn{2}{|c|}{ Soil water content at FC $(\%, g / g)$} & \multicolumn{2}{|c|}{ Soil water content at PWP $(\%, \mathrm{~g} / \mathrm{g})$} \\
\hline & PSD & $\mathrm{PSD}+\mathrm{OC}$ & PSD & $\mathrm{PSD}+\mathrm{OC}$ \\
\hline Intercept & $27.80^{* * *}$ & $24.98^{* * *}$ & $10.06^{* * *}$ & $4.341^{* * *}$ \\
\hline Sand $(\%)$ & $-0.231^{* * *}$ & $-0.205^{* * *}$ & $-0.0847^{* * *}$ & \\
\hline Clay (\%) & $0.262^{* * *}$ & $0.28^{* * *}$ & $0.303^{* * *}$ & $0.435^{* * *}$ \\
\hline $\mathrm{OC}\left(\mathrm{g} \mathrm{kg}^{-1}\right)$ & & $0.192^{* * *}$ & & \\
\hline Sand $\times$ Clay & & & $-0.00186^{* * *}$ & $-0.00431^{* * *}$ \\
\hline Sand $\times$ OC & & & & $0.00190^{* * *}$ \\
\hline Clay $\times$ OC & & & & $0.00169^{* * *}$ \\
\hline & $R^{2}=0.61$ & $R^{2}=0.63$ & $R^{2}=0.73$ & $R^{2}=0.72$ \\
\hline
\end{tabular}

Values given in the table represents the coefficients of PTF model in the form of multiple linear regression equation as mentioned in equation (2) along with their significant levels.

${ }^{* * *}$ and ${ }^{* *}$ represent significance level at $<0.1 \%$ and $<1 \%$, respectively.

(a)

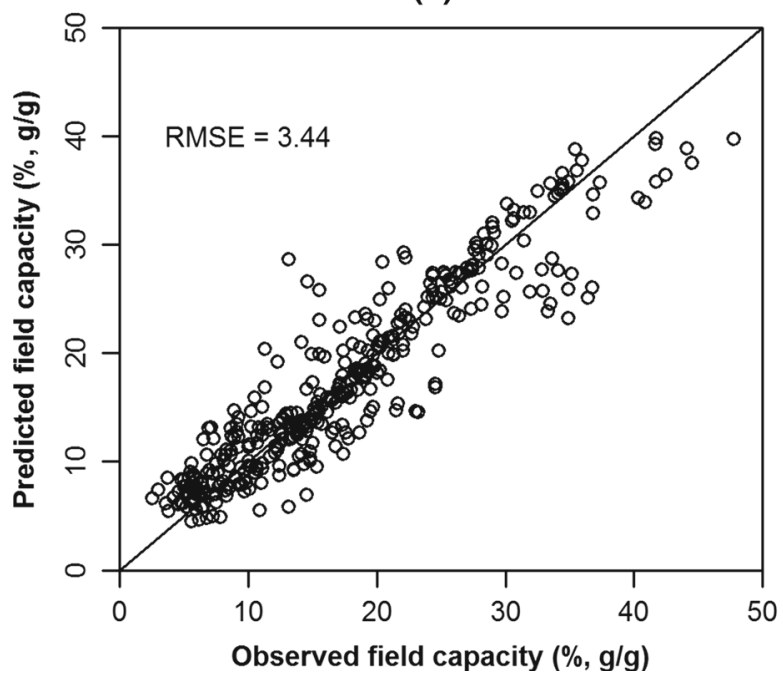

(b)

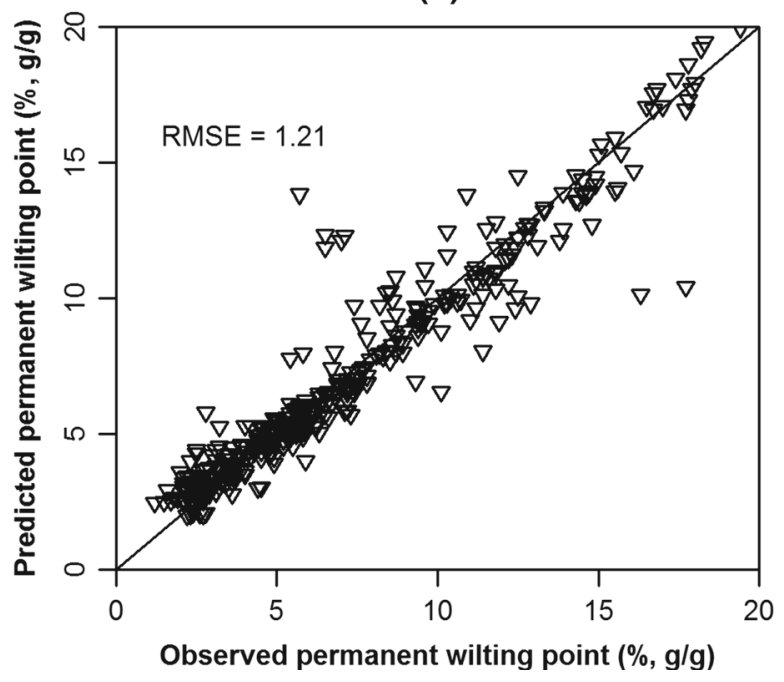

Figure 4. Cross validation of observed and $\mathrm{PTF}_{\mathrm{SAWI}}(\mathrm{PSD}+\mathrm{OC})$-estimated water content at field capacity $(\%$, g/g) and permanent wilting point $(\%, \mathrm{~g} / \mathrm{g})$. Solid line is the $1: 1$ line.

indicating that predicted values are larger than observed values. The 'established' PTFs showed positive bias in estimation of FC except in comparison with the PTF by Chakraborty et al. (2011). In case of PWP, bias was found negative for both the developed PTFs and 'established' PTFs except for the PTF by Adhikary et al. (2008). However, when the developed PTFs as well as 'established' PTFs were tested using the independent dataset from an arid region of USA, overall positive bias was observed, indicating a tendency for underprediction. The difference in observed and estimated values by 'established' PTFs was due to differences in soil properties represented in the testing database versus the range of soil properties from which the 'established' PTFs were developed. For example, sand content was very high and OC content very low in the testing database 'Jsm', in comparison to the range of soil properties using which 'established' PTFs were developed. Similar observations on non-portability of PTFs to other regions have been reported elsewhere (van Den Berg et al. 1997; Wösten et al. 1999; Hodnett and Tomasella 2002; Balland et al. 2008). The estimation performance of $\mathrm{PTF}_{\mathrm{SAWI}}$ in 'USA-arid' database is also presented in figure 5 (c and d). Overall, the estimated values of soil water content at FC were evenly distributed around the 1:1 line whereas for PWP, it showed negative bias.

Comparative performance of the PTFs developed in this study and the 'established' PTFs using both test datasets, 'Jsm' and 'USA-arid', in terms 
(a)

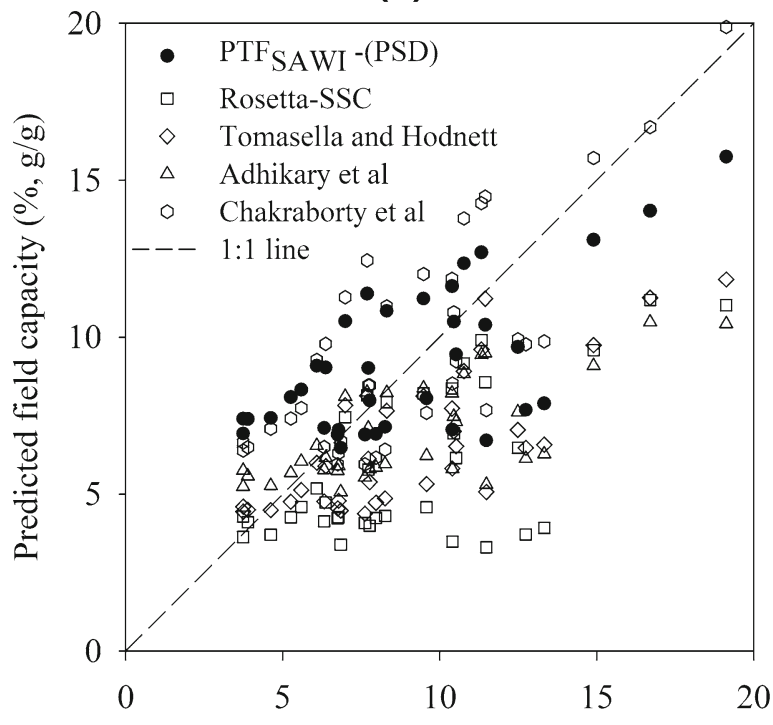

Observed field capacity $(\%, \mathrm{~g} / \mathrm{g})$

(c)

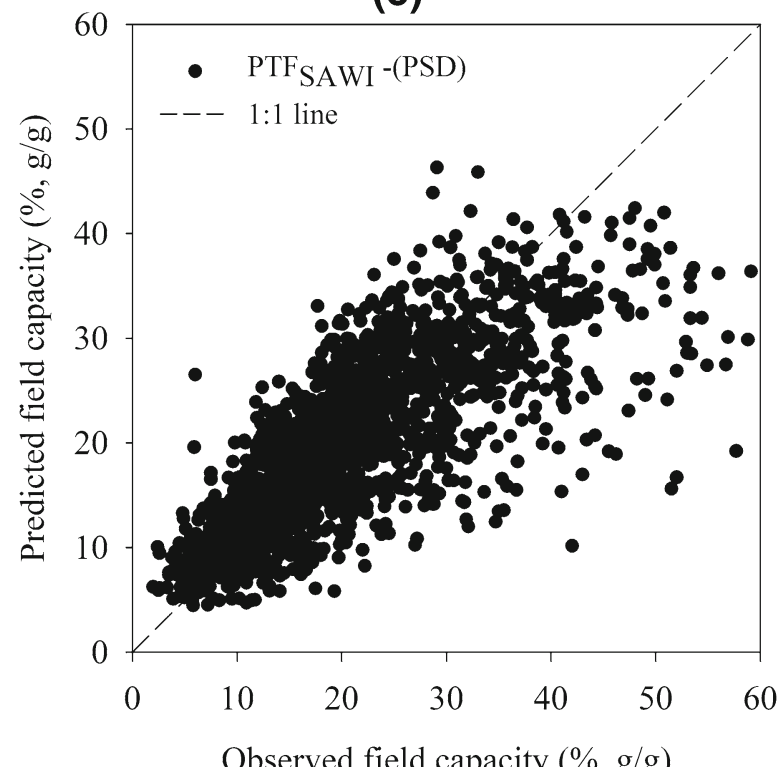

(b)

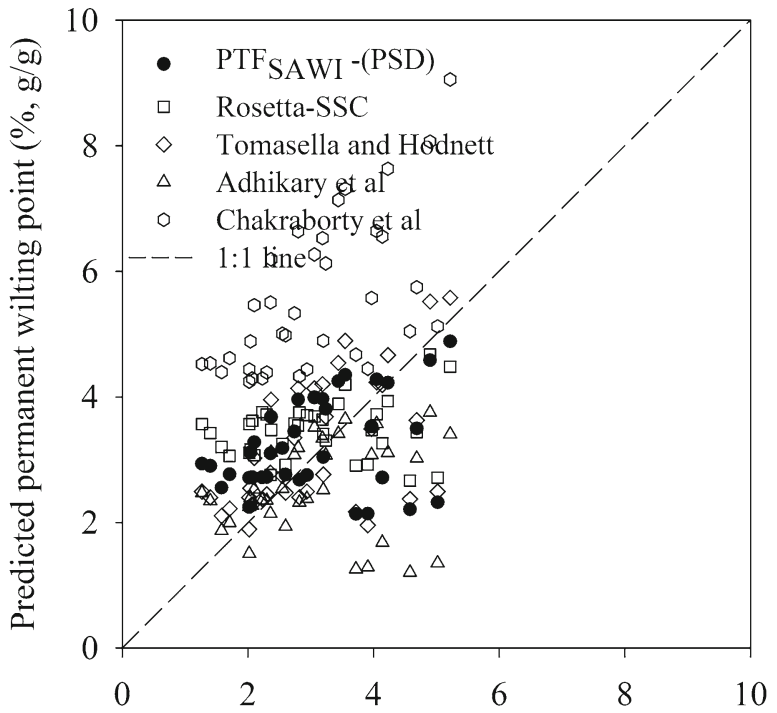

Observed permanent wilting point $(\%, \mathrm{~g} / \mathrm{g})$

(d)

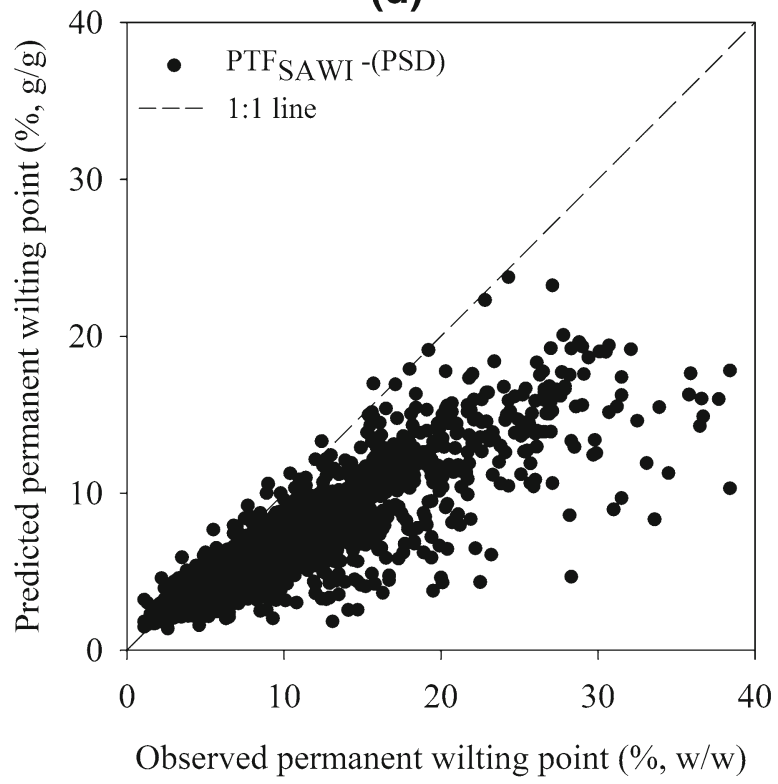

Figure 5. Comparative performance of PTFs developed in this study with selected 'established' PTFs to estimate soil water content at FC (\%,g/g) and PWP (\%,g/g), using independent soil databases (a and b) from Jaisalmer region of hot Arid Western India; (c and $\mathbf{d}$ ) from arid region of USA.

of RMSE, is presented in table 8. Performance of $\mathrm{PTF}_{\mathrm{SAWI}}$ was better in 'Jsm' database as shown by lower RMSE values as compared to other 'established' PTFs. However, when PTF SAwI was applied to data from an arid region of the USA to estimate soil water content at FC and PWP, the performance was better than for other 'established' PTFs, but not better than for global PTFs.

Comparative analysis of developed PTFs and 'established' PTFs in both datasets indicated that the performance of global PTFs was best, whereas in 'Jsm' database performance of $\mathrm{PTF}_{\text {SAWI }}$ was superior. This indicates the problem of limited portability of PTFs, even within similar soilclimatic regions. Soil properties or pedological features of the dataset to which a given PTF is to be applied need to be similar to those represented in the original dataset from which a PTF was developed. However, when global PTFs developed from the merged database from arid regions 


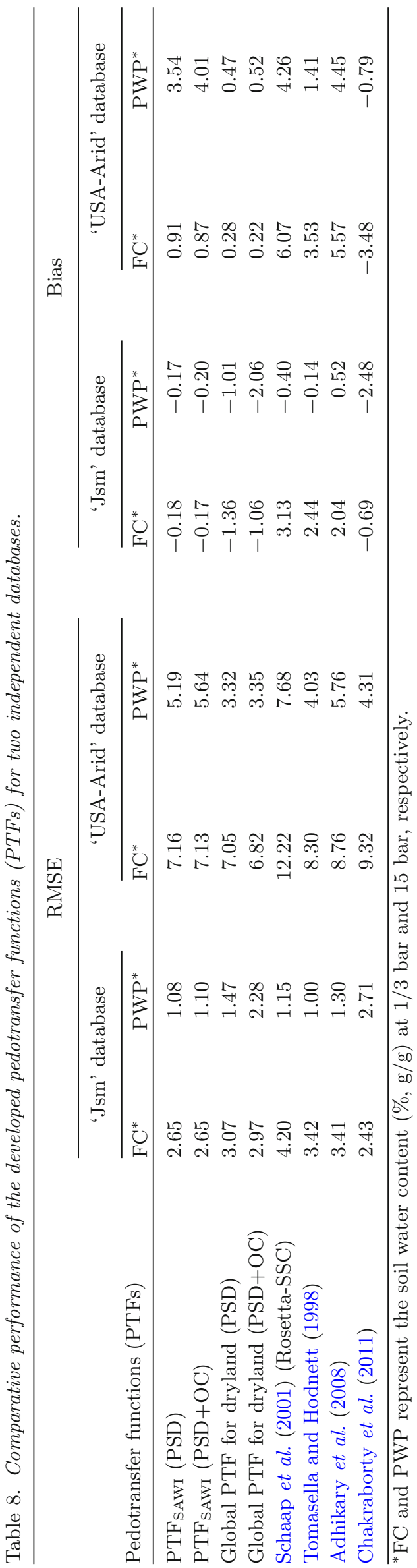

of India and USA were tested, they showed better performance in both the testing dataset, whether from India or USA. Therefore, we recommend the PTF $_{\text {SAWI }}$ for more accurate estimation of FC and PWP within hot Arid Western India, while global PTFs will be more accurate for drylands elsewhere in the world. Among the 'established' PTFs, those of Tomasella and Hodnett (1998) performed better than others in this study, both for the 'Jsm' and 'USA-arid' databases (see table 8). Specifically, it may be noted here that the PTFs by Tomasella and Hodnett (1998) outperformed the PTF SAWI $_{\text {and }}$ global PTF in the 'Jsm' database, when estimating soil water content at PWP. Alternatively, the PTF by Chakraborty et al. (2011) outperformed $\mathrm{PTF}_{\text {SAWI }}$ and global PTF while estimating soil water content at FC in the 'Jsm' database.

\subsection{PTF based soil moisture calculator}

For wide applicability of the developed PTFs, a user-friendly soil moisture calculator, 'CAZRI soil moisture calculator' was developed; it may be downloaded from http://www.cazri.res.in/soil-moi sture-calc.php (figure 6). First, using a pull-down menu, users must choose the appropriate PTF. Subsequently, for any field, users must enter the sand, silt, clay and OC content. Upon pressing 'enter', the FC and PWP are calculated.

For arid regions in India, we recommend the $\mathrm{PTF}_{\text {SAWI }}$ models that consider either the PSD or $\mathrm{PSD}+\mathrm{OC}$ category depending on the availability of input data. In the CAZRI soil moisture calculator these models are referred to as CAZRI PTF model. However, for dry lands elsewhere in the world, global PTFs may be selected using the dropdown menu for model selection. Apart from dry lands, the calculator may also be used elsewhere in India or tropical countries of the world, since it also contains the robust PTF model of Tomasella and Hodnett (1998), Adhikary et al. (2008) and Chakraborty et al. (2011).

Knowledge on estimated critical soil moisture constants may guide the farmers to apply the right amount of irrigation water at the right time, possibly with support of an extension service. For example, in a farmer's field with sand, silt and clay content of 87,8 and $5 \%$, respectively, the estimate of soil water content at FC and PWP will be 7.90 and $2.60 \%(\mathrm{~g} / \mathrm{g})$, respectively, if CAZRI PTF model $\left(\mathrm{PTF}_{\mathrm{SAWI}}\right)$ with PSD category of input data is selected. These estimates will further lead to an estimate of maximum plant available soil water 


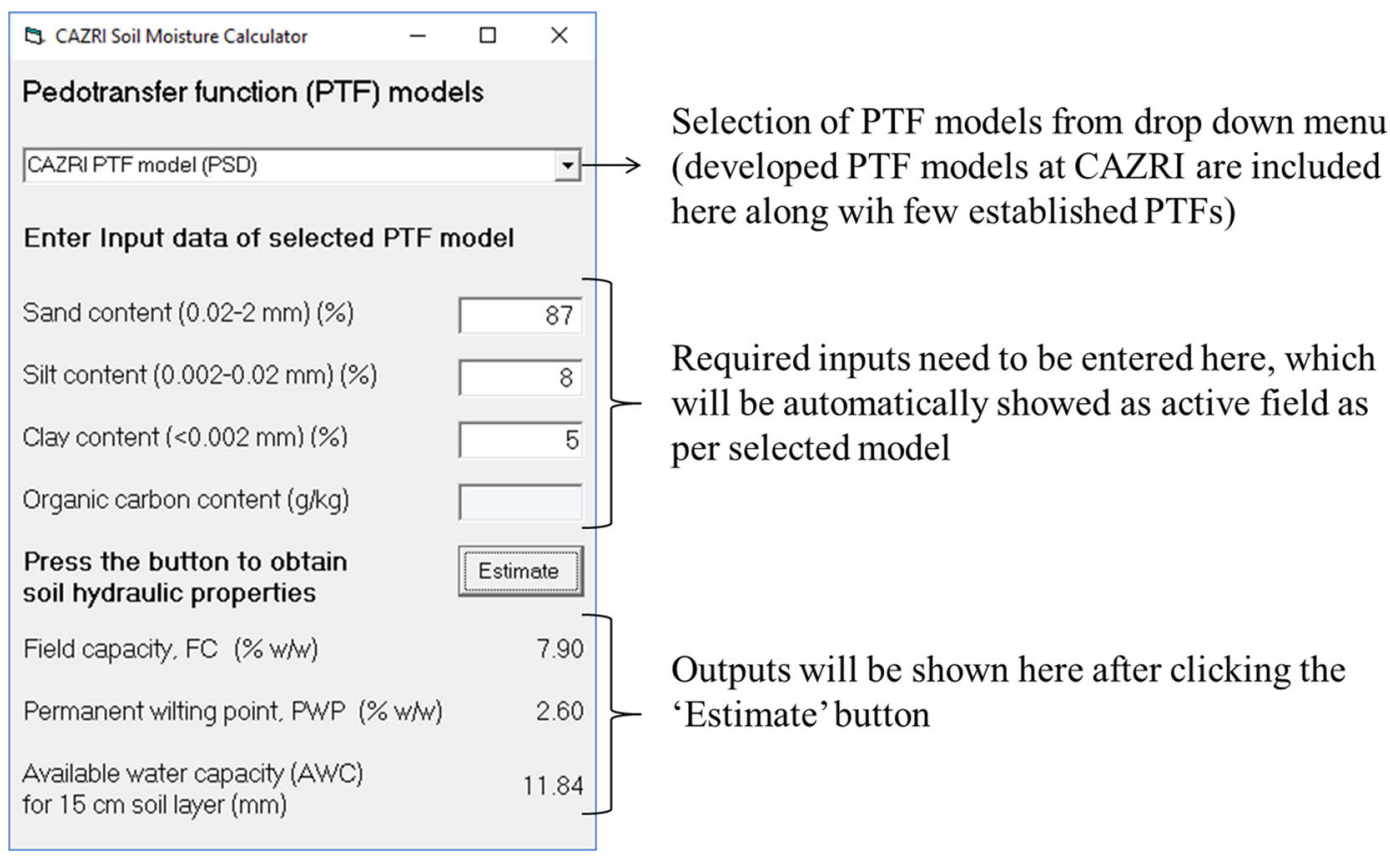

Figure 6. Software console of PTF based CAZRI soil moisture calculator.

of $11.8 \mathrm{~mm}$ in surface soil $(0-15 \mathrm{~cm})$ assuming an average bulk density of $1.49 \mathrm{Mg} \mathrm{m}^{-3}$ for arid western India, as found in the SAWI database. For example, if a farmer wishes to apply irrigation at $50 \%$ soil moisture depletion then he should irrigate the field when soil water content dries to $5.25 \%(\mathrm{~g} / \mathrm{g})$ from FC level [soil moisture content after $50 \%$ depletion $=\mathrm{FC}-0.5 \times(\mathrm{FC}-\mathrm{PWP})]$ and the required quantity of irrigation water will be $59.2 \mathrm{~m}^{3} \mathrm{ha}^{-1}$ for bringing the soil moisture level of the $0-15 \mathrm{~cm}$ soil layer again to $\mathrm{FC}$ level [required amount of water $=(\mathrm{FC}-$ soil moisture $) \times$ bulk density $\times$ soil depth $\times$ area to be irrigated]. In the above calculation, a linear decrease in soil water content during the process of soil drying was assumed. For a more accurate estimation of the required amount of water, a curvilinear relationship between water potential $(h)$ and soil water content $(\theta)$ may be considered, but this would require tedious field monitoring of soil water suction levels using a tensiometer. The CAZRI soil moisture calculator developed in the context of this study may help extension workers to assist farmers in saving the scarce water resources, while maintaining the required productivity.

\section{Conclusions}

PTFs were developed to estimate soil water content at FC and PWP, drawing on a soil database for
Arid Western India, with the aim to allow for judicious use of scarce water resources in dry land agriculture. Evaluation of the developed PTFs showed satisfactory performance in cross-validation. However, when these local PTFs were applied to a soil dataset for arid USA, the performance was not satisfactory. To address the problem of lack of portability of local PTFs across regions, we developed a set of global PTFs using the merged database for soils from arid regions of India and USA. These global PTFs performed better than other 'established' PTFs, both for the test dataset from India and from the USA. The PTFs developed in this study will be used by extension workers to help dry land farmers save scarce irrigation water through judicious irrigation scheduling.

\section{Acknowledgements}

We express our sincere thanks to the Director, ICAR-CAZRI Jodhpur for providing necessary support to carry out the present study (CAZRI/T04/31). The senior author (PS) also expresses his sincere thanks to the National Director, NAIP (ICAR), Director CAZRI and Dr P C Pande, Head of Division CAZRI for providing the opportunity for foreign training in Geoinformatics, and to Dr H M C van Holsteijn, Director a.i. of ISRICWorld Soil Information, The Netherlands, for hosting PS as a guest researcher working on 'spatial assessment of soil properties using digital soil 
mapping techniques' (Sept.-Dec. 2013). We thank the Editor and reviewers for their detailed and insightful comments that helped to improve the paper.

\section{References}

Adhikary P P, Chakraborty D, Kalra N, Sachdev C B, Patra A K, Kumar S, Tomar R K, Chandna P, Raghav D, Agrawal K and Sehgal M 2008 Pedotransfer functions for predicting the hydraulic properties of Indian soils; Soil Res. 46(5) 476-484.

Balland V, Pollacco J A P and Arp P A 2008 Modeling soil hydraulic properties for a wide range of soil conditions; Ecol. Model. 219 300-316.

Bell M A and Van Keulen H 1996 Effect of soil disturbance on pedotransfer function development for field capacity; Soil Technol. 8(4) 321-329.

Bhattacharya T, Sarkar D and Pal D K 2009 Soil Survey Manual, NBSS \& LUP Publication No. 146, National Bureau of Soil Survey \& Land Use Planning (Indian Council for Agricultural Research), Nagpur, India, 400p.

Botula Y D, Nemes A, Mafuka P, Van Ranst E and Cornelis W M 2013 Prediction of water retention of soils from the humid tropics by the nonparametric-nearest neighbor approach; Vadose Zone J. 12(2) 1-17, https://doi.org/ $10.2136 /$ vzj2012.0123.

CAZRI 2008 Annual Report; Central Arid Zone Research Institute, Jodhpur, India.

Chakraborty D, Mazumdar S P, Garg R N, Banerjee S, Santra P, Singh R and Tomar R K 2011 Pedotransfer functions for predicting points on the moisture retention curve of Indian soils; Indian J. Agric. Sci. 81(11) 1030.

Cornelis W M, Ronsyn J, van Meirvenne M and Hartmann R 2001 Evaluation of pedotransfer functions for predicting the soil moisture retention curve; Soil Sci. Soc. Am. J. 65 638-648.

D'Odorico P, Bhattachan A, Davis K F, Ravi S and Runyan C W 2013 Global desertification: Drivers and feedbacks; Adv. Water Res. 51 326-344.

Gupta S C and Kapoor V K 2000 Fundamentals of mathematical statistics: A modern approach; Sultan Chand and Sons.

Gupta S C and Larson W E 1979 Estimating soil water characteristics from particle size distribution, organic matter percent, and bulk density; Water Resour. Res. 151633 1635.

Haghverdi A, Leib B G and Cornelis W M 2015 A simple nearest-neighbor technique to predict the soil water retention curve; Trans. ASABE 58(3) 697-705.

Hodnett M G and Tomasella J 2002 Marked differences between van Genuchten soil water-retention parameters for temperate and tropical soils: A new water-retention pedo-transfer functions developed for tropical soils; Geoderma 108 155-180.

Khlosi M, Alhamdoosh M, Douaik A, Gabriels D and Cornelis W M 2016 Enhanced pedotransfer functions with support vector machines to predict water retention of calcareous soil; Eur. J. Soil Sci. 67(3) 276-284.
Klute A 1986 Water retention: Laboratory methods; In: Methods of soil analysis. Part I: Physical and Mineralogical Methods. Agronomy Series 9, 2nd edn, American Society of Agronomy, Madison, WI, USA, pp. 635-662.

Millennium Ecosystem Assessment 2005 Ecosystems and human well-being: Desertification synthesis; World Resources Institute, Washington, DC.

Minasny B and McBratney A B 2002 The neuro-m method for fitting neural network parametric pedotransfer functions; Soil Sci. Soc. Am. J. 66 352-361.

Mohanty M, Sinha N K, Painuli D K, Bandyopadhyay K K, Hati K M, Reddy K S and Chaudhary R S 2015 Modelling soil water contents at field capacity and permanent wilting point using artificial neural network for Indian soils; Nat. Acad. Sci. Lett. 38(5) 373-377.

Nemes A, Schaap M G and Wösten J H M 2003 Functional evaluation of pedotransfer functions derived from different scale of data collection; Soil Sci. Soc. Am. J. 671093 1102.

Patil N, Pal D, Mandal C and Mandal D 2012 Soil water retention characteristics of vertisols and pedotransfer functions based on nearest neighbor and neural networks approaches to estimate AWC; J. Irrig. Drain Eng. 138(2) 177-184.

R Core Team 2013 R: A language and environment for statistical computing; R Foundation for Statistical Computing, Vienna, Austria, http://www.R-project.org/.

Rawls W J, Brakensiek D L and Saxton K E 1982 Estimation of soil water properties; Trans. ASAE 25 1316-1320.

Rijsberman F R 2006 Water scarcity: Fact or fiction? Agric. Water Manag. 80 5-22.

Romano N and Palladino M 2002 Prediction of soil water retention using soil physical data and terrain attributes; J. Hydrol. 265 56-75.

Santra P and Das B S 2008 Pedotransfer functions for soil hydraulic properties from a hilly watershed of eastern India; Geoderma 146 439-448.

Sarma V A K, Krishnan P and Budihal S L 1987 Soil resources mapping of different states in India: Laboratory manual; Technical Bulletin No. 14, National Bureau of Soil Survey \& Land Use Planning (Indian Council for Agricultural Research), Nagpur, India, 49p.

Sehgal J L, Saxena R K and Vadive1u S 1987 Soil resource mapping of different states in India: Field manual (2nd edn), Technical Bulletin No. 13, National Bureau of Soil Survey \& Land Use Planning (Indian Council for Agricultural Research), Nagpur, India, 73p.

Schaap M G, Leij F J and van Genuchten M Th 2001 Rosetta: A computer program for estimating soil hydraulic parameters with hierarchical pedotransfer functions; J. Hydrol. 251 163-176.

Schewe J, Heinke J, Gerten D, Haddeland I, Arnell N W, Clark D B, Dankers R, Eisner S, Fekete B M, ColónGonzález F J, Gosling S N, Kim H, Liu X, Masaki Y, Portmann F T, Satoh Y, Stacke T, Tang Q, Wada Y, Wisser D, Albrecht T, Frieler K, Piontek F, Warszawski L and Kabat P 2013 Multimodel assessment of water scarcity under climate change; Proc. Natl. Acad. Sci., https://doi.org/10.1073/pnas.1222460110.

Sharma J P, Giri J D, Shyampura R L and Gajbhiye K S 2006 Soil series of Gujarata; NBSS\&LUP Publication No. 120, National Bureau of Soil Survey \& Land Use 
Planning (Indian Council for Agricultural Research), Nagpur, India, 329p.

Shwetha P, Varija K and Kumar P 2013 Study on soil moisture retention function for the Indian forested hillslope soils; J. GeoEng. 8(1) 11-18.

Shyampura R L, Singh S K, Singh R S, Jain B L and Gajbhiye K S 2002 Soil series of Rajasthan; NBSS\&LUP Publication No. 96, National Bureau of Soil Survey \& Land Use Planning (Indian Council for Agricultural Research), Nagpur, India, 329p.

Singh A K 2000 Use of pedotransfer functions in crop growth simulations; J. Water Manag. 8 18-21.

Soil Survey Staff 1996 Soil survey laboratory methods manual. Soil Survey Investigations Report 42 (ver. 3), United States Department of Agriculture, Lincoln, NE, http://www.nrcs.usda.gov/Internet/FSE_ DOCUMENTS/16/nrcs143_019356.pdf.

Soil Survey Staff 2010 Keys to soil taxonomy, 11th edn, USDA-Natural Resources Conservation Service, Washington, DC, ftp://ftp-fc.sc.egov.usda.gov/NSSC/ Soil_Taxonomy/keys/2010_Keys_to_Soil_Taxonomy.pdf.

Tietje O and Tapkenhenrichs M 1993 Evaluation of pedotransfer functions; Soil Sci. Soc. Am. J. 571088-1095.

Tomasella J and Hodnett M G 1998 Estimating soil water retention characteristics from limited data in Brazilian Amazonia; Soil Sci. 163 190-202.

Unger P W 1975 Water retention by core and sieved soil samples; Soil Sci. Soc. Am. Proc. 39 1197-1200.

van Den Berg M, Klamt E, van Reeuwijk L P and Sombroek W G 1997 Pedotransfer functions for the estimation moisture retention characteristics of ferrasols and related soils; Geoderma 78 161-180.

van Reeuwijk L P 2002 Procedures for soil analysis; 6th edn, Technical Paper 9, International Soil Reference Centre (ISRIC), Wageningen.

Corresponding editor: Prashant K SRIVAstava
Vereecken H, Maes J, Feyen J and Darius P 1989 Estimating the soil moisture retention characteristics from texture, bulk density and carbon content; Soil Sci. 148 389403.

Vörösmarty C J, Green P, Salisbury J and Lammers R B 2000 Global water resources: Vulnerability from climate change and population growth; Science $289284-$ 288.

Wagner B, Tarnawski V R, Hennings V, Müller U, Wessolek G and Plagge R 2001 Evaluation of pedo-transfer functions for unsaturated soil hydraulic conductivity using an independent data set; Geoderma 102(3) 275-297.

Walkley A and Black I A 1934 An examination of Degtjareff method for determining soil organic matter, and a proposed modification of the chromic acid titration method; Soil Sci. 37 29-38.

Wösten J H M and van Genuchten M Th 1988 Using textures and other soil properties to predict the unsaturated soil hydraulic functions; Soil Sci. Soc. Am. J. 521762 1770.

Wösten J H M, Lilly A, Nemes A and Le Bas C 1999 Development and use of a database of hydraulic properties of European soils; Geoderma 90 169-185.

Wösten J H M, Verzandvoort S J E, Leenaars J G B, Hoogland T and Wesseling J G 2013 Soil hydraulic information for river basin studies in semi-arid regions; Geoderma 195-196 79-86.

Young K K and Dixon J D 1966 Overestimation of water content at field capacity from sieved sample data; Soil Sci. 101 104-107.

Zhao C, Shao M A, Jia X, Nasir M and Zhang C 2016 Using pedotransfer functions to estimate soil hydraulic conductivity in the Loess Plateau of China; Catena 143 1-6.

http://ncsslabdatamart.sc.egov.usda.gov/ NCCS Soil Characterization Database. 